\title{
To Work out the Economics of Various Recipes of R.T.S.
}

\author{
Ashwini K. Abhangrao ${ }^{1 *}$, A.K. Naidu ${ }^{2}$, S.S. Yadlod ${ }^{1}$ and Manisha Deshmukh ${ }^{3}$ \\ ${ }^{1}$ Vasantrao Naik Marathwada Krishi Vidyapeeth Parbhani, Maharashtra, India \\ ${ }^{2}$ Jawaharlal Nehru Krishi Vishwa Vidyapeeth Jabalpur, M.P., India \\ ${ }^{3}$ Punjabrao Deshmukh Krishi Vidyapeeth, Akola, India \\ *Corresponding author
}

\section{A B S T R A C T}

\section{Keywords \\ Lucknow-49, Apple guava, RTS, TSS, Comparative cost, Economics \\ Article Info \\ Accepted: \\ 26 March 2017 Available Online: 10 May 2017}

The fruits of Lucknow-49, red fleshed variety and apple guava were collected from the orchard of the College of Agriculture Jabalpur (M.P.). The fruits were collected from the winter season crop (2007). Fully matured fruits were picked up and sorted, washed, cutted into pieces, mixing with water (1:1) then passed through - pulper to get guava pulp preparation after that guava pulp mixed with strained syrup solution recipe (sugar+ water +acid and heated just to dissolve according to recipe), homogenization, cooling (at $40^{\circ} \mathrm{C}$ addition of sodium benzoate $750 \mathrm{ppm}$ ), filter, bottling, crown corking, pasteurization $\left(82^{\circ} \mathrm{C}\right.$ for $\left.15 \mathrm{~min}\right)$, cooling for RTS product. Physico - chemical characters [sensory quality characters (color, flavor, Taste, overall acceptability), total soluble solids, $\mathrm{pH}$, percent acidity, ascorbic acid content $(\mathrm{mg} / 100 \mathrm{mg})]$ for $0^{\text {th, }} 30^{\text {th }}, 60^{\text {th }}$ days of observation were recorded. In experiment recipe 1 was $10 \%$ pulp, $11 \%$ T.S.S., $0.3 \%$ acidity, recipe 2 was $10 \%$ pulp, $11 \%$ T.S.S., $0.4 \%$ acidity. And recipe 3 was $10 \%$ pulp, $12 \%$ T.S.S., $0.3 \%$ acidity, recipe 4 was $10 \%$ pulp, $12 \%$ T.S.S., $0.4 \%$ acidity. Recipe 5 was $10 \%$ pulp, $13 \%$ T.S.S., $0.3 \%$ acidity, recipe 6 was $10 \%$ pulp, $13 \%$ T.S.S., $0.4 \%$ acidity was used. After work out the economics, the comparative cost of 1 lit RTS prepared by guava pulp, from recipe 1 cost 6.02 Rs. and second best recipe 5 was cost 6.52 Rs. However, its cost was high as compared to recipe 2, 4 and 3. Among the cultivars Lucknow-49 were found good for RTS preparation.

\section{Introduction}

Guava (Psidium guajava L.) is one of the most nutricious fruit. It is richer source of vitamin" C" than Ber, Citrus and apple. Guava is grown commercially in North India because of its higher yielding capacity and good economic returns. In India, Uttar Pradesh the largest grower produces best quality of Guava Bihar, Madhya Pradesh, Andhra Pradesh, Tamil nadu, West Bengal, Punjab, Assam, Karnataka, Maharashtra are chief producers of quality guava. India occupies nearly 150.9 lakh hectares of area with a production of 1710.6 million tonnes and with a productivity of 10.77 tonnes fruit per hectare per year(Yadav 2002).

The storage of fruit is very difficult for longer period because of its perishable nature especially under tropical condition. It is common experienced that $20-25 \%$ of the fruit is completely damaged and spoiled before it reaches to the consumers (Yadav, 1997). Therefore it is necessary to develop technology for better utilization of such a 
perishable fruits. In the state also it is grown large scale and often it causes glut in the local market. To overcome these problems there is need to find out suitable low cost processing techniques.

Therefore to utilize the produce at the time of glut and to save it from spoilage the development of low cost processing technology of guava fruit is need of time it will also generate enough opportunities of self employment by starting small scale processing unit or cottage industry which will be renumerate to the growers thus the preparation of guava RTS beverage have a great scope. Now a day, the beverage is becoming popular comparison to synthetic or aerated drinks.

\section{Materials and Methods}

The fruits of Lucknow-49, Red fleshed guava, apple guava were collected from the orchard of the college of Agriculture J.N.K.V.V. (M.P.). The fruits were collected from the winter season crop (2007) fully matured fruits were picked up and sorted out for the preparation of RTS. Fruits were cut into small pieces, it can be sieved to get pulp, small pieces of guava were mixed with water 1:1 and straining pulp, pulp was taken and dissolved with water after that TSS $(11,12$ and $13^{\circ}$ brix) and acidity (0.3 and 0.4 percent) were maintained with help of sugar and citric acid as per recipe. The workout of economics of the treatment by the cost of sugar, KMS, fuel, labour, and fruit etc was calculated.

\section{Results and Discussion}

The cost of one litre product was estimated and presented in tables 1 and 2. The best cultivar Lucknow-49 was chosen and the cost of all expenses was worked out. The total expenditure for preparation of RTS for 6.75 for recipe $R_{6}$ followed by recipe $R_{5}$ (6.52), recipe $R_{3}$ (6.48), recipe $R_{4}(6.30)$, recipe $R_{2}$ (6.25) and recipe $R_{1}$ (6.02).

It was evident from the preparation that the cost involvement in the preparation of RTS different recipes is different. The total cost of RTS from recipes $R_{1}$ is less overall other recipes and declared best recipes for RTS preparation according to cost and for RTS preparation according to cost and quality, recipe $R_{5}$ was second best recipe however, the cost of recipe $R_{5}$ was high as compared to recipe $R_{2}, R_{4}$ and $R_{3}$. The cost of involvement in various recipes used in preparation of guava RTS.

Table.1 Economics of pulp (10 kg pulp)

Economics of treatments

\begin{tabular}{|l|l|r|}
\hline Sr.no. & \multicolumn{1}{|c|}{ Particulars } & In Rupees \\
\hline 1 & Cost of 20 Kg guava & 160.00 \\
\hline 2 & Labour charge & 50.00 \\
\hline 3 & KMS & 8.00 \\
\hline 4 & Fuel & 10.00 \\
\hline $\begin{array}{l}\text { Total } \\
\text { expenditure }\end{array}$ & & 228.00 \\
\hline $\begin{array}{l}\text { Cost of 1 } \\
\text { Kg pulp }\end{array}$ & & 22.80 \\
\hline
\end{tabular}


Table.2 Economics of RTS prepared by various recipes

\begin{tabular}{|l|l|c|c|c|c|c|c|}
\hline Sr.no. & Particulars & $\mathbf{R}_{\mathbf{1}}$ & $\mathbf{R}_{\mathbf{2}}$ & $\mathbf{R}_{\mathbf{3}}$ & $\mathbf{R}_{\mathbf{3}}$ & $\mathbf{R}_{\mathbf{4}}$ & $\mathbf{R}_{\mathbf{5}}$ \\
\hline 1 & $\begin{array}{l}\text { Cost of } \\
\text { pulp 1 kg }\end{array}$ & 22.80 & 22.80 & 22.80 & 22.80 & 22.80 & 22.80 \\
\hline 2 & $\begin{array}{l}\text { Cost of } \\
\text { sugar }\end{array}$ & 16.50 & 18.00 & 19.50 & 16.50 & 18.00 & 19.50 \\
\hline 3 & $\begin{array}{l}\text { Cost of } \\
\text { Citric acid }\end{array}$ & 12.00 & 13.00 & 14.00 & 15.00 & 16.00 & 17.00 \\
\hline 4 & $\begin{array}{l}\text { Labour } \\
\text { charge }\end{array}$ & 15.00 & 15.00 & 15.00 & 15.00 & 15.00 & 15.00 \\
\hline $\begin{array}{l}\text { Total } \\
\text { expenditure(Rs) }\end{array}$ & & 66.30 & 68.00 & 71.30 & 69.30 & 71.00 & 74.30 \\
\hline $\begin{array}{l}\text { Total } \\
\text { expenditure } \\
\text { (RTS in litres) }\end{array}$ & & 11.00 & 11.00 & 11.00 & 11.00 & 11.00 & 11.00 \\
\hline $\begin{array}{l}\text { Cost of } \\
\text { production } \\
\text { Rs/lit }\end{array}$ & & 6.02 & 6.25 & & & & \\
\hline
\end{tabular}

In conclusion a study on the comparative cost of 1 litre RTS prepared by guava pulp from recipe $R_{1}$ cost Rs 6.02 and second best recipe $\mathrm{R}_{5}$ was cost 6.52 . However its cost was high as compared to recipe 2, 4 and 3 among the cultivars Lucknow-49 were found good for RTS preparation.

\section{References}

A.O.A.C. (1980). Method of Analysis of the Association of Official Agricultural Chemists, Washington,D.C.,USA.

Amerine, M.A., Pangborn,R.M. and Rossler,E.B.(1965). Principles of sensory evaluation of food academic Press, New York.

Baramanray,A., Gupta O.P. and Dhawan, S.S. (1995).Evaluation of Guava (Psidium guajava $L$.) hybrids for making nectar. Haryana J.Hort. Sci., 24(4):196-204

Bose T.K., Mitra,S. K; farooqui,A.A. and sandhu, M.K. (1999).Tropical Horticulture,1:pp-297.

Chatterjee,D., Singh, U.P., Thakur, S. and Kumar, R.(1992).A note on the bearing habit of guava (Psidium guajava L.). Haryana.J.Hort.sci., 21(1 and 2):69-71

Deka B.C., Vijay sethi, poonam, suneja; Shrivastava, V.K. (2004).Physicochemical changes of lime- aonla Spiced beverage during storage. Journal of Food science and Technology, Mysore., 41(3):329-332.

DekaB.C., Vijaysethi, Anantasaikia (2005). Changes in quality of mangopineapple spiced beverage during storage. Indian journal of Horticulture, 62(1): 71-75.

Garg,N., Kalra, S.K. and Tondon, D.K.(1993).Quality evaluation of market raw mango powder and mango leather.Beverage and Food World,20(2):13-14, 18.

Harisimrat, K. Bons and S.S. Dhawan (2003). Effect of preserved guava pulp on the quality of ready to serve beverage. Centre of food Science and technology CCS Haryana Agriculture University,Hisar.Crop Res.,25(2):360363(2003). 
Harnanan, S.W., Bains, G.S. and Singh K.K. (1980). Studies on processing of pink and white fleshed guava varieties of pulp.

Harisimrat,K. and Dhawan,S.S (1998). Preparation of guava fruit bar poster abstract.IFCON, 0-40:533.

Imran Ahmad; Rafinullah Khan; Muhammad Ayub(2000).Effect of added sugar at various concentration on the storage stability of guava pulp. Sarhad Journal of Agriculture, 16(1):89-93.

Iqbal,S., Yasmin, A;Wadud, S., Shah,W.H.(2001) Production, storage,packing and quality evaluation of guava nectar.Pakistan Journal Of Food Sciences(Pakistan)V.II(1-4)p 33-36.

Jain P.K. and Asati, V.K.(2004). Evaluation of Guava cultivars for pulp preparation.Journal Of Food ScienceandTechnology,Mysore 41(6):684-686

Jain,S.K., Khuradiya, D.S.(2004). Vitamin ' $C$ ' enrichment of fruit juice base blending of Indian gooseberry(EmblicaofficnalisGaertn) juice. Plants Foods For Human Nutrition, 59(2):63-66.

Jain, V;Tiwari.B.L. and Sharma, H.G.(1997).Evauation of early mango varieties for preparation of beverage as nectar and RTS. Orissa j.Hort., 25 (1):40-45:8 ref.

Kalra,S.K. andRevanthi, G.(1983). Chemical and microbial evaluation stored guava pulp in P.V.C container.J.Fd. Sci. Technology.,20(3): 118-120.

Khburdiya,D.S. and Sagar, V.R.(1991).Note on processing and storage of guava nectar. Indian J.Hort., 48(1):19-21.

Kumar, R.S., Manimegalai,G.(2005).Studies on storage stability of whey based papaya juice blended R.T.S beverage. Journal of food Science and Technology, Mysore 42(2):185-188.
Pagano Garcia,F., Medina Bracamonte M.L., Araujo,F.(2002).Evaluation of Free amino acids in guava (Psidium guajava L.) pulp destined for nectar preparation.

Palaniswamy, K.P., Mathurkrishnan, C.R. Shanmugvelu, K.G. (1974) studied on evaluation of certain mango varieties of Tamil Nadu for pulp destined for nectar production.

Pandey A.K. (2004).Study about the storage storability of Guava Beverage. Progressive Horticulture, 36(1):142145.

Pandey A.K.(2004) and Singh I.S.(1999).Studies on preparation of guava ready to serve beverage. Indian J. Hort., 56(2):130-132.

Pandey, K.K.; Sharma A.B. and Patel M.P. (1997). The varietals evaluation of Guava (Psidium guajava L.) Ad. Plant Sci., 10(1):157-163.

PandeyA.K., andsingh I.S.(1998).Physicochemical studies on utilization of guava cultivars. Progressive Horticulture, 30(1/2): 73-75.

Proceedings of the Inter american Society for Tropical Horticulture, 20000;42:292296.

Panse PV, Sukhatme VG (1967) Statistical method of agricultural worker. ICAR publication, New Delhi.

Rabbani,A. (1992).Studies on post -harvest technology of sucking Mangoes. Ph.D Thesis N.D. Univ. Agric.Technol., Faizabad.

Ramajayam,D., Jagannath, S., Syamsundar, Joshi, Sivakumar, K.C. (2002). Preparation of ready to serve (RTs) and squashes from simarouba fruits. Current Research University of Agricultural Sciences,Banglore,31(7/8): 111-113.

Roy,K.S. And Singh,R.N. (1979).Studies on utilization on bael fruit for processing.Indian Fd.Packer,46(6):19- 
22.

Sagar,V.R. and Maini, S.B.(1993).Economic Utilization of rainy season guava drying aspects. Indian Fd.Packer,46(6):19-22.

Sahni,C.K., Khurdiya, D.S. and Dalal,M.A.(1994).Studies on quality and carotene profile of mango pulp as influenced by temperature and aditives. Indian J.Hort., 51(3):229233.

Sarvanan, K., Godara,R.K.,Goyal, R.K. Sharma, R.K.(2004).Processing of papaya fruit for the preparation of ready to serve beverage and it's quality.Indian Journal of Hill Farming 14(1/2):49-55.

Sethi V. and Jindal, P.C. (1997). Evaluation of new grape hybrid juice for processing. Haryana J. Hort.Sci., 26(34): 208
Sethi, V. and Maini, S.B. (1991). Studies on storage of Mango pulp. Indian J. Hort.,48(8):228-231.

Shrivastava, R.P. and Kumar, S.(1992).Fruit and vegetable preservation principles and practices, pp. 81-83.

Singh B.P., Kalra, S.K., Tondon D.K.(1990). Behaviour of Guava cultivars during ripening and Storage.Haryana Journal of Horticulture Sciences, 19:1-2 1-6; II ref.

Snecdor, G.M. and Cochron, W.C. (1967). Statastical methods Oxford and IBH Publishing Co. Calcntia

Tondon, D.K., Kalra, S.K., Singh, H., Chadha,K.I(1983).Physico-chemical characterstics or same guava Varieties.Progressive Horticulture, 15:1/2,42-44; 8 ref

\section{How to cite this article:}

Ashwini K. Abhangrao, A.K. Naidu, S.S. Yadlod and Manisha Deshmukh. 2017. To Work out the Economics of Various Recipes of R.T.S. Int.J.Curr.Microbiol.App.Sci. 6(5): 2861-2865. doi: https://doi.org/10.20546/ijcmas.2017.605.324 